MARKETING AND BRANDING
RESEARCH $\begin{gathered}\text { INDUSTRIAL } \\ \text { MANAGEMENT } \\ \text { INSTITUTE }\end{gathered}$

\title{
Customer Loyalty: The Effect of Service Quality, Corporate Image, Customer Relationship Marketing and Customer Satisfaction as Intervening Variable-An Empirical Analysis of Bank Customers in Malang City
}

\author{
Hellen Karyose $^{1}$, Widji Astuti ${ }^{2} *$ Achmad Ferdiansjah $^{2}$ \\ ${ }^{1}$ Mutiara Harapan School-Malang \\ ${ }^{2}$ University of Merdeka Malang
}

\begin{abstract}
Keywords:

Service Quality,

Corporate Image,

Customer Relationship

Marketing, Customer

Satisfaction, Customer

Loyalty

Correspondence:

This study aimed to analyze the influence of service quality, corporate image, and customer relationship marketing on customer satisfaction and customer loyalty. The population consisted of 180 bank customers in Malang city. For the analysis of Structural Equation Model (SEM) came into use. The results showed that service quality, corporate image, and customer relationship marketing influence on customer satisfaction, and service quality, corporate image, and customer relationship marketing influence on customer loyalty. Moreover, customer satisfaction effects on customer loyalty. Customer satisfaction mediated the effect of service quality, corporate image, and customer relationship marketing on customer loyalty.
\end{abstract}

Dee.xaxo@gmail.com

\section{Introduction}

Today, the development of the banking world is very rapid. Increased competition in Indonesian banking began with the deregulation of Indonesian banking with the policy package of June $1^{\text {st }}, 1983$ (PAKJUN) with the aim of modernizing the banking system and then continued with the October Package (PAKTO) on October $27^{\text {th }}, 1988$, which facilitated the establishment of new bank licenses 
including the opening of branch offices. Competition between banks has expanded with the emergence of new products with various attributes and facilities.

Maintaining bank customers to remain loyal to bank services, bank management needs to pay attention to the quality of services provided. Service quality is a global attitude or judgment about the superiority of a service, although the true scope of this attitude has no uniformity of opinion (Robinson, 1999). Al-Rousanand Mohamed (2010), Akbar, Som, Wadood, and Alzaidiyeen (2010), Malik, Yaqoob, and Aslam (2012), Bostanji (2013) and Poku, Zakari, and Soali (2013) concluded that the quality of service has significant influence on customer loyalty. On the other hand, Cristobal, Flavian, and Guinaliu (2007),indicated that service quality does not affect customer loyalty.

The previous research gap on the impact of service quality in establishing and maintaining customer loyalty gives the direction that excellent service to customers needs to be accompanied by a good bank image in the eyes of customers, because the image of the bank ultimately provides consumer ratings for the credibility of the bank. Malik, et al. (2012) concluded that the image affects loyalty; following this, Lu and Liping (2009) concluded that the image affects loyalty but the image does not affect customer satisfaction. Different results are shown by Bloemer, Ruyter, and Peeters (1998) who stated that the image did not affect consumer loyalty.

The results of this study provide the direction that in addition to service quality and image of the bank there are other things that make customers survive or lead to loyal Customer Relationship Marketing. According to Kotler and Armstrong (2008), CRM in Relational Marketing concepts is the whole process of building and maintaining profitable customer relationships by delivering value and customer satisfaction. The study of Jesri, Ahmadi, and Fatehipoor (2013) concluded that CRM significantly affects customer loyalty. The results of the study by Wang and Yang (2010) indicated that there is no significant relationship between CRM and loyalty.

The result of empirical study about the influence of service quality, image, and customer relationship marketing on customer loyalty still cause gap to be reviewed and to cover the gap, mediator influence of service quality and image on customer loyalty is needed. Customers are not easy to be loyal if they have not felt customer satisfaction. The experience of obtaining customer satisfaction can be binding to be loyal. So customer satisfaction is a mediation that has been done by the bank to customer loyalty.

The role of customer satisfaction as mediating the influence of service quality, bank image, and customer relationship marketing is based on the result of previous empirical study about the influence between service quality, bank image, and customer relationship marketing on customer satisfaction and influence of satisfaction on customer loyalty. Parasuraman, Zeithaml, and Berry (1988) have previously stated that high quality of service produces high customer satisfaction as well. The study of Abdullah and Francine (2009), Kwortnik and Han (2011), Kim, Cha, Singh, and Knutson(2013), and Gunarathne (2014) showed that there is influence of service quality on customer satisfaction. The research of Kuo and Tang (2013) can contribute to customer satisfaction of Roche (2014);following this, Ghanian, Ghoochani, \& Crotts (2014) concluded that corporate image has an effect on customer satisfaction and the result of research by Fornell, Johnson, Anderson, Cha, and Bryant (1996), Mohajerani (2013), and Saleem and Raja (2014) indicated that customer satisfaction influences customer loyalty. This study aimed to analyze the influence of service quality, corporate image, and customer relationship marketing on customer satisfaction and customer loyalty.

\section{The Literature Review}

\section{Service Quality}

In general, the quality of service is the attitude or global judgment about the superiority of the service, although the actual scope of this attitude has no uniformity of opinion (Robinson, 1999). Service 
quality is often conceptualized as a comparison of expectations with perceptions of actual performance of services (Zeithaml \& Bitner, 2003). According to Kotler and Keller (2006), service quality is the unity of characteristic of a good or service that by counting on its ability tries to satisfy stated needs. According to Zeithaml and Bitner (2003), there are five main dimensions of service quality, namely tangibles including physical facilities, equipment, personnel, and means of communication; reliability such as the ability of staff to deliver promised service and provide satisfactory service; responsiveness, which is the desire of the staff to help the customers and provide services with responsiveness; assurance including the knowledge, capability, courtesy, and credibility of the staff, free from harm, risk, and doubt; and empathy which includes the ease of doing relationships, good communication, personal attention, and understanding the needs of the customers.

\section{Image}

According to Kotler and Keller (2006), image refers to a set of opinions, thoughts, and actions that a person keeps considering an object. People's behaviours and actions towards an object are greatly conditioned by that object's image. Meanwhile, according to Assael (1984), an image is considered as the overall perception of the subject that is shaped by managing information from different sources over time.

Peter and Olson (2005) suggest factors affecting the image include leadership, policies and strategies, human resources policy, wealth management, process management, customer satisfaction, employee satisfaction, social responsibility, and business results. Milferner, Snoj, and Korda (2011) revealed the company's image indicators consisting of location, price conformity, service reputation, and promotion. Harrison (2000) discloses complete information about the company's image including the four elements, namelypersonality, the overall characteristics of a company that the target public understands such as a trustworthy company, a company with social responsibility; reputation, what the company has done and is believed to be the target public based on its own experience as well as other parties such as the security performance of a bank's transactions; value- values owned by a company in other words corporate culture such as management attitudes that care about customers, employees are quick responsive to requests and customer complaints; and corporate identity, components that facilitate the introduction of targeted public to companies such as logos, colors, and slogans.

\section{Customer Relationship Marketing}

Customer relationship marketing (CRM) has evolved into a new paradigm for marketing strategy. CRM seeks to extend the lifespan of customers. CRM is a combination of business processes and technologies that aim to understand customers from various prospects to differentiate their products and services on a competitive basis (Kotler\& Keller, 2006). CRM is a concept that focuses on maintaining relationships with customers to build long-term and profitable relationships with customers (Buttle, 2009). According to Buttle (2009), CRM aims to develop profitable relationships and realize value for target consumers profitable by integrating internal processes and functions with all external networks.

The factors that make up customer relationship marketing according to Ndubisi and Wah (2005) are trust, commitment, communication, complaint handling, and competence. While Ndubisi (2007) argue that the forming of CRM is commitment, communication, and complaint handling. There are several measures of customer relationship marketing (Gronroos, 1990), namely Long-term customer focus, making communication with customers, engaging member organizations in marketing activities, implementation of interactive marketing process, developing a service culture for customers, and obtain and using information from customers. 


\section{Customer Satisfaction}

Engel, Blackwell, and Miniard (1995) assume that customer satisfaction is an after-sales assessment whereby the selected alternative is at least equal to or exceeds the customer's expectations, whereas dissatisfaction emerges when the results do not meet expectations. According to Kotler and Keller (2006),customer satisfaction is the level of one's feelings after comparing perceived performance compared to expectations. Generally, a customer's expectation is an estimate or a customer's belief about what he or she will receive when buying and consuming a product. While perceived performance is "customer perception of what is received after consuming the purchased product".

Considering the assessment of satisfaction or discontent based on the expectancy disconfirmation model there are three types, namely positive disconfirmation (when performance exceeds expected), simple disconfirmation (if both are the same), and negative disconfirmation (if performance is worse than expected). The difficulty with this model is that no definite conceptualization of standard comparisons and disconfirmation constructs has been found (Tse \& Wilton, 1988).

\section{Customer Loyalty}

According to Griffin (2002), loyalty is defined as non-random purchase manifested over time by some decision-making unit. Based on the definition it appears that loyalty is directed to a behavior, which is indicated by regular purchases, based on the decision-making unit. Customer loyalty has an important role in a company, maintaining them means improving company performance; this is the main reason for a company to attract and maintain.

Customer loyalty can be measured by indicators, namely the willingness of customers to make the company as the first choice; the willingness of customers to buy products offered by customers; the willingness of the customer to invite others to buy; and the willingness of customers to tell about good things about the company (Foster \& Cadogan, 2000). While the indicator of customer loyalty according to Kotler and Keller (2006) is repeat purchase (loyalty to the purchase of the product); retention (resilience to negative influence of company); and referrals (references totally corporate essence). Nguyen, Sherif, \&Newby (2007)reveals that loyal customers will consider themselves faithful because of an object as a first and foremost choice, a desire to always transact and recommend to others. Sung and Chang (2005) revealed that customer loyalty is formed due to favorable wording, repetitive purchase, and intention of repurchase.

\section{Research Hypotheses \\ Quality of service, bank image, and customer relationship marketing have a significant effect on customer satisfaction}

Parasuraman et al. (1988) has previously stated that high service quality resulted in high customer satisfaction. Abdullah and Francine (2009), Kwortnik and Han (2013), Kim et al. (2013), and Gunarathne (2014) indicate that there is an influence of service quality on customer satisfaction.

Image is an award earned by the company because of the superiority of excellence in the company such as the ability owned by the company, so the company will keep developing themselves to continue to create new things again for the fulfillment of consumer needs (Herbig, Milewicz, \& Golden, 1994). Kuo and Tang (2013) shows that corporate image has an effect on customer satisfaction. Roche (2014) and Ghanian et al. (2014) concluded that corporate image had an effect on satisfaction of banking sector customers in Sri Lanka.

In addition to quality service and image, customer relationship marketing contributes to customer satisfaction. 
$\mathbf{H}_{1}$ : Quality of service, bankimage, and customer relationship marketing have significant effect on customer satisfaction.

Quality of service, bank image, and customer relationship marketing have a significant effect on customer loyalty

Quality must start from customer needs and end in customer perception (Kotler\& Keller, 2006). This means that good quality is not from the perspective or perception of the service provider, but it is based on the point of view on the customer's perception. Research by Al-Rousanand Mohamed (2010), Akbar et al. (2010), Malik et al. (2012), Bostanji (2013), and Poku et al. (2013) conclude that there is a significant relationship between service quality and customer loyalty.

Image is a perception of the company. The positive consumer perception of a company creates a continuing acceptance of a good and the end product is the desire to repurchase. Previous research by Lu and Liping (2009) Malik et al. (2012) concluded that the image has positive and significant impact on customer loyalty.

According to Kotler and Armstrong (2008), CRM in relational marketing concepts refers to the entire process of building and preserving benefisial customer relationships by delivering superior customer value and satisfaction. Jesri et al. (2013) concluded that CRM significantly affects the loyalty of Mehr Bank customers in Iran.

$\mathbf{H}_{2}$ : Quality of service, bank image, and customer relationship marketing significantly influence customer loyalty.

\section{Customer satisfaction has a significant effect on customer loyalty}

Consumer satisfaction is a success in meeting customer needs and desires. Customer satisfaction encourages customers to re-purchase because they do not want to move and ultimately can benefit economically as well as "word of mouth" publicity (Fornell, 1992). Research conducted by Akbar et al. (2010), Mohajerani (2013), and Saleem and Raja (2014) showed that customer satisfaction has an effect on customer loyalty.

$\mathbf{H}_{3}$ : Customer satisfaction has a significant effect on customer loyalty.

Quality of service, bank image, and customer relationship marketing have significant effect on customer loyalty through customer satisfaction.

A number of previous studies by Abdullah and Francine (2009), Kwortnik and Han (2013), Kim et al. (2013), and Gunarathne (2014) presented that service quality has influence on customer satisfaction. Moreover, Kuo and Tang (2013) expressed that corporate image has an effect on customer satisfaction. Roche (2014) concluded that the company's image had an effect on customer satisfaction in the banking sector in Sri Lankan. Ghanian et al. (2014) concluded that the image has a significant positive effect on customer satisfaction. Akbar et al. (2010), Mohajerani (2013), and Saleem and Raja (2014) showed that customer satisfaction influences customer loyalty.

$\mathbf{H}_{4}$ : Quality of service, bank image, and customer relationship marketing significantly effect on customer loyalty through customer satisfaction 


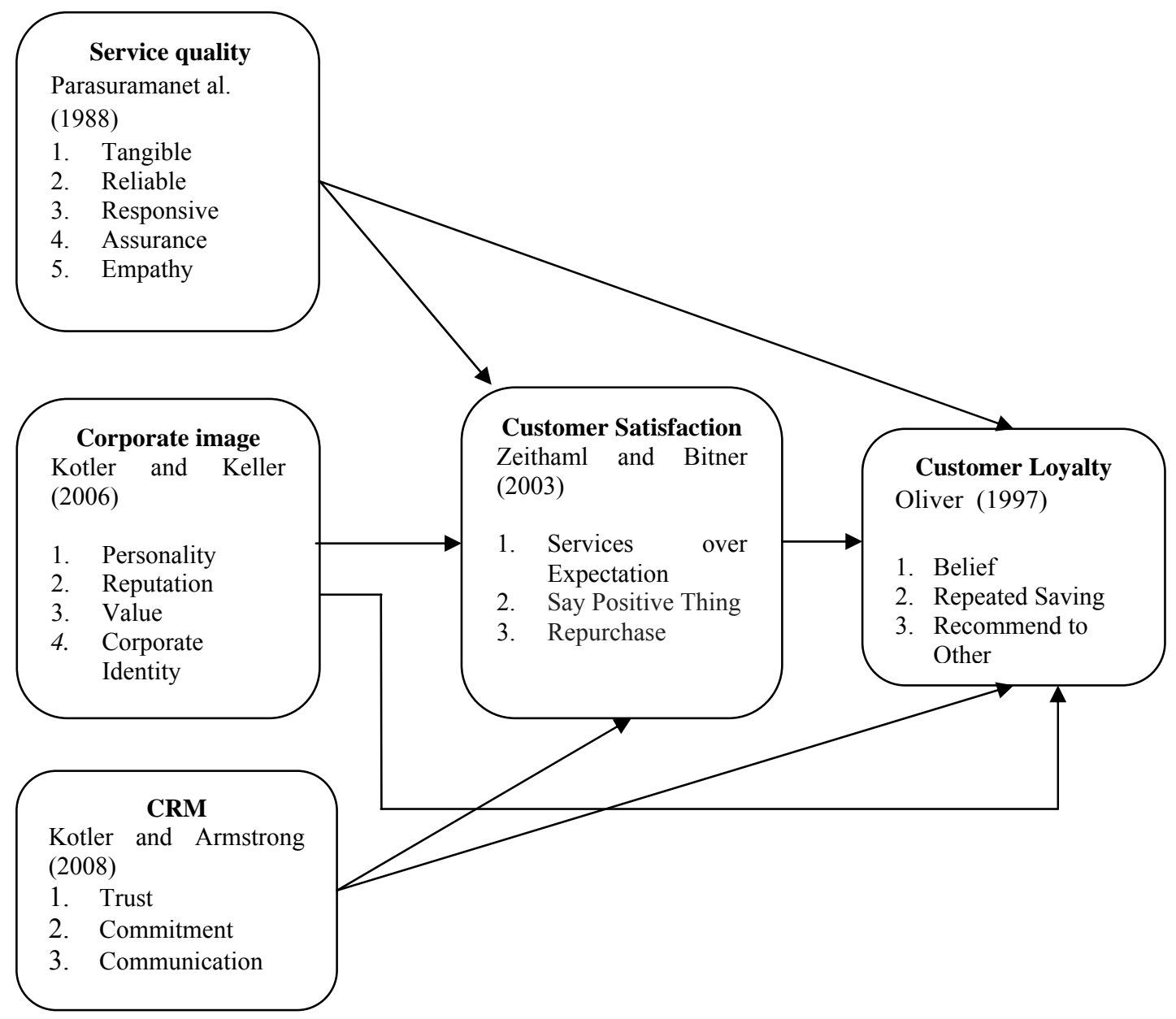

Figure 1.Conceptual framework

\section{Method}

The study used a quantitative approach with an explanatory research design. Data collection techniques were conducted by survey. The study population consisted of 180 bank customers in Malang city. The number of population was infinite population, then the size of the sample was determined based on analytical techniques. Sampling technique is purposive sampling, with criterion of choosing respondents who are real bank customers that open bank account in Malang City and become customer by saving their money for minimum 3 years. In the current study, data analysis technique using Structural Equation Modeling (SEM) came into use. Hypothesis testing is done using coefficient CR (critical ratio) analogous to t-test prob. (P); if $\mathrm{p}>0.05$ then $\mathrm{H}_{0}$ is accepted and if $\mathrm{p} \leq$ 0.05 then $\mathrm{H}_{0}$ is rejected. If the total influence is greater than the direct effect, then the hypothesis is accepted, so the variable of customer satisfaction as a variable mediate the influence of service quality, bank image, and customer relationship marketing on customer loyalty.

\section{Results}

Service Quality is measured by five indicators, namelytangibles, reliability, responsiveness, assurance, and empathy. Corporate image contains four indicators including personality, reputation, value, and corporate identity. Customer Relationship Marketing consists of three indicators such as trust, commitment, and communication. Following this, customer satisfaction is measured by three 
indicators, namelyservices over expectation, saying positive thing, and repurchase; and then, customer loyalty is measured by three indicators including belief, repeating, and recommending to other.

Table 1 presents the validity and reliability instrument. According to Table 1, all variables are valid; moreover, alpha value for all variable is greater than 0.6 which means that the measuring instrument for research has a high consistency.

Table1

Validity and Reliability Instrument

\begin{tabular}{|c|c|c|c|c|c|}
\hline \multirow{2}{*}{ Variable } & \multirow{2}{*}{ Item } & \multicolumn{2}{|c|}{ Correlation } & \multicolumn{2}{|c|}{ Coefficient } \\
\hline & & $\mathrm{r}$ & status & alpha & status \\
\hline \multirow{10}{*}{ Service Quality } & $\mathrm{X} 1.1$ & 0.79 & Valid & \multirow{10}{*}{0.88} & \multirow{10}{*}{ Reliable } \\
\hline & $\mathrm{X} 1.2$ & 0.68 & Valid & & \\
\hline & $\mathrm{X} 1.3$ & 0.69 & Valid & & \\
\hline & $\mathrm{X} 1.4$ & 0.73 & Valid & & \\
\hline & $\mathrm{X} 1.5$ & 0.40 & Valid & & \\
\hline & $\mathrm{X} 1.6$ & 0.78 & Valid & & \\
\hline & $\mathrm{X} 1.7$ & 0.74 & Valid & & \\
\hline & $\mathrm{X} 1.8$ & 0.76 & Valid & & \\
\hline & X1.9 & 0.73 & Valid & & \\
\hline & $\mathrm{X} 1.10$ & 0.74 & Valid & & \\
\hline \multirow{8}{*}{ Corporate Image } & $\mathrm{X} 2.1$ & 0.77 & Valid & \multirow{8}{*}{0.89} & \multirow{8}{*}{ Reliable } \\
\hline & $\mathrm{X} 2.2$ & 0.75 & Valid & & \\
\hline & $\mathrm{X} 2.3$ & 0.84 & Valid & & \\
\hline & X2.4 & 0.75 & Valid & & \\
\hline & $\mathrm{X} 2.5$ & 0.68 & Valid & & \\
\hline & $\mathrm{X} 2.6$ & 0.81 & Valid & & \\
\hline & $\mathrm{X} 2.7$ & 0.77 & Valid & & \\
\hline & $\mathrm{X} 2.8$ & 0.74 & Valid & & \\
\hline \multirow{6}{*}{$\begin{array}{l}\text { Customer Relationship } \\
\text { Marketing }\end{array}$} & X3.1 & 0.79 & Valid & \multirow{6}{*}{0.81} & \multirow{6}{*}{ Reliable } \\
\hline & $\mathrm{X} 3.2$ & 0.88 & Valid & & \\
\hline & X3.3 & 0.84 & Valid & & \\
\hline & X3.4 & 0.87 & Valid & & \\
\hline & $\mathrm{X} 3.5$ & 0.83 & Valid & & \\
\hline & X3.6 & 0.80 & Valid & & \\
\hline \multirow{6}{*}{ Customer Satisfactions } & Y1.1 & 0.75 & Valid & \multirow{6}{*}{0.81} & \multirow{6}{*}{ Reliable } \\
\hline & $\mathrm{Y} 1.2$ & 0.72 & Valid & & \\
\hline & Y1.3 & 0.77 & Valid & & \\
\hline & Y1.4 & 0.78 & Valid & & \\
\hline & Y1.5 & 0.70 & Valid & & \\
\hline & Y1.6 & 0.66 & Valid & & \\
\hline \multirow{6}{*}{ Customer Loyalty } & Y2.1 & 0.85 & Valid & \multirow{6}{*}{0.81} & \multirow{6}{*}{ Realibe } \\
\hline & Y2.2 & 0.88 & Valid & & \\
\hline & Y2.3 & 0.81 & Valid & & \\
\hline & Y2.4 & 0.80 & Valid & & \\
\hline & Y2.5 & 0.72 & Valid & & \\
\hline & Y2.6 & 0.92 & Valid & & \\
\hline
\end{tabular}

\section{Feasibility Analysis of the Model}

Relationship among research variable shows a high level of significance that is $0.00<0.05$; this means that the linearity assumption is met. Table 2 shows overall goodness of fit. 
Table 2

Goodness of Fit

\begin{tabular}{cccc}
\hline Criteria & Cut-Off Value & Result & Keterangan \\
\hline Chi-Square & small & 298.201 & Model Marginal \\
p-value & $\geq 0.05$ & 0.00 & Good \\
CMIN/DF & $\leq 2.00$ & 2.33 & Good \\
GFI & $\geq 0.90$ & 0.85 & Model Marginal \\
AGFI & $\geq 0.90$ & 0.80 & Good \\
TLI & $\geq 0.95$ & 0.78 & Good \\
CFI & $\geq 0.95$ & 0.80 & Good \\
RMSEA & $\leq 0.08$ & 0.06 & \\
\hline
\end{tabular}

Results of Structural Equation Model (SEM) with AMOS 6.0 is given in Figure 1.

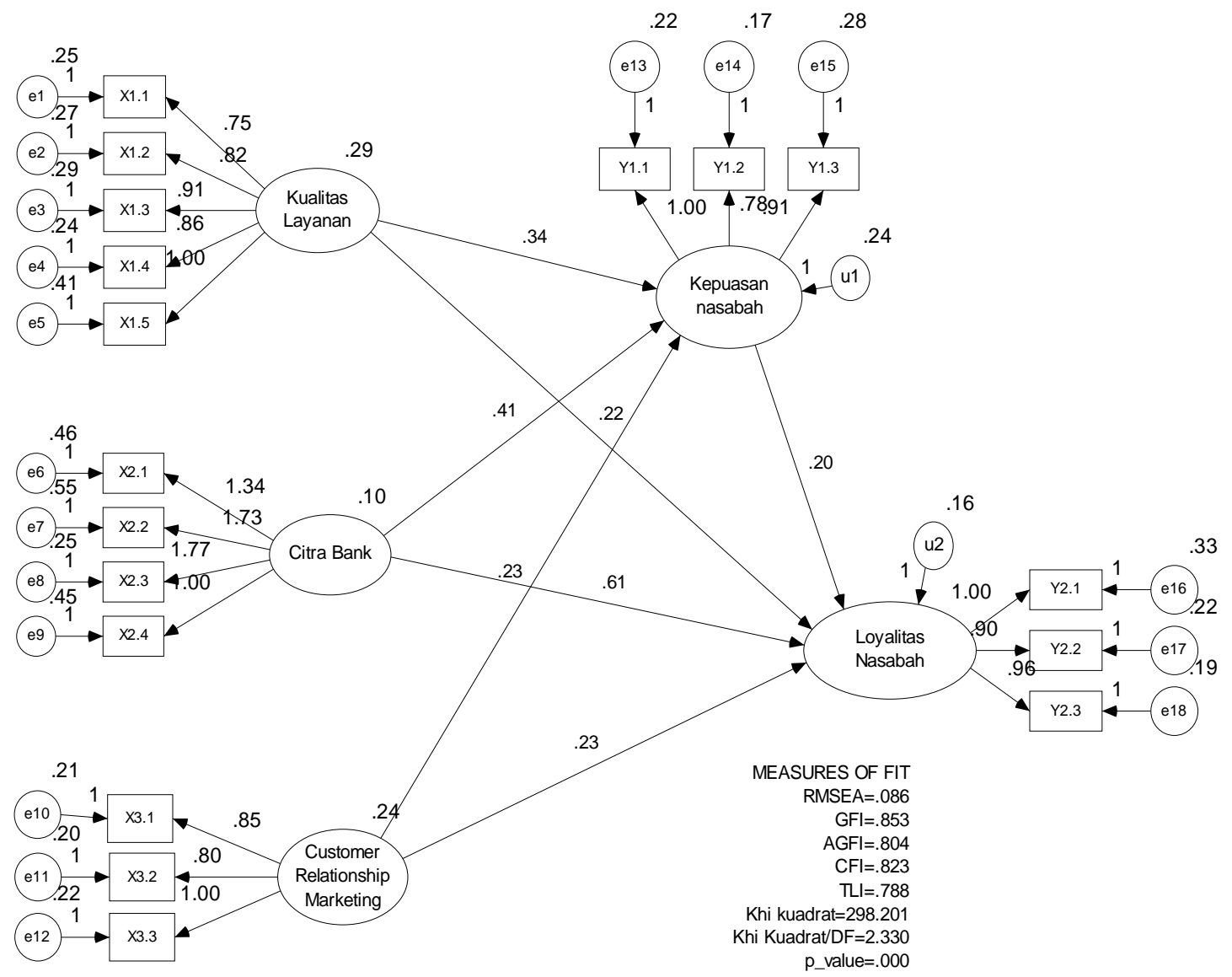

Figure 2. Model SEM

Table 3 exhibits the regression weight. 
Table 3

Regression Weight

\begin{tabular}{ccccccc}
\hline & Description & & Path Coeff & C.r. & P-Value & Result \\
\hline Customer Satisfaction & $<-$ & Service Quality & 0.28 & 2.63 & 0.00 & Significant \\
Customer Satisfaction & $<-$ & Corporate image & 0.20 & 2.57 & 0.01 & Significant \\
Customer Satisfaction & $<-$ & CRM & 0.34 & 3.28 & 0.00 & Significant \\
Customer Loyalty & $<-$ & Service Quality & 0.23 & 2.13 & 0.03 & Significant \\
Customer Loyalty & $<-$ & Corporate image & 0.16 & 2.01 & 0.04 & Significant \\
Customer Loyalty & $<-$ & CRM & 0.22 & 2.00 & 0.04 & Significant \\
Customer Loyalty & $<-$ & Customer Satisfaction & 0.21 & 1.97 & 0.04 & Significant \\
\hline
\end{tabular}

The effect of service quality on customer satisfaction resulted in $\mathrm{Cr}$ value of 2.63 with p-value of $0.00<\alpha \quad 0.05$; so that service quality had significant effect on customer satisfaction. The effect of corporate image on customer satisfaction resulted in $\mathrm{Cr}$ value of 2.57 with p-value of $0.00<\alpha 0.05$; so that corporate image had a significant effect on customer satisfaction. The influence of customer relationship marketing on customer satisfaction resulted in $\mathrm{Cr}$ value of 3.28 with p-value equal to 0.00 $<\alpha 005$; so that customer relationship marketing had significant effect on customer satisfaction. Thus, $\mathrm{H} 1$, service quality, corporate image, and customer relationship Marketing have a positive and significant impact on proven customer satisfaction.

The influence of service quality on customer loyalty resulted in $\mathrm{Cr}$ value of 2.13 with p-value of $0.03<\alpha \quad 0.05$; so service quality had significant effect on customer loyalty. The effect of corporate image on customer loyalty resulted in $\mathrm{Cr}$ value of 2.01 with p-value of $0.04<\alpha 0.05$; so that corporate image had significant effect on customer loyalty. The influence of customer relationship marketing oncustomer loyalty resulted in $\mathrm{Cr}$ value equal to 2.00 with p-value equal to $0.04<\alpha 0,05$; so customer relationship marketing had significant effect oncustomer loyalty. Hence, $\mathrm{H}_{2}$, service quality, corporate image, and customer relationship marketing have positive and significant impact on customer loyalty. The influence of customer satisfaction on customer loyalty resulted in Cr value of 1.97 with p-value of $0.04<\alpha 0.05$; so $\mathrm{H}_{3}$, customer satisfaction had positive and significant impact on customer loyalty.

Table 4 represents the hypotheses testing results.

Table4

Hypotheses Testing Results

\begin{tabular}{lccc} 
Influence Between Variables & Direct Effect & Indirect effect & Total Effect \\
\hline Service Qualityon Customer Satisfaction & 0.28 & - & 0.28 \\
Corporate Imageon Customer Satisfaction & 0.20 & - & 0.20 \\
Crmon Customer Satisfaction & 0.34 & - & 0.34 \\
Service Qualityon Customer Loyalty & 0.23 & $0.28 \times 0.21=0.05$ & 0.29 \\
Corporate Imageon Customer Loyalty & 0.16 & $0.20 \times 0.21=0.04$ & 0.20 \\
Customer Loyalty & 0.22 & $0.34 \times 0.21=0.07$ & 0.29 \\
Customer Satisfaction Customer Loyalty & 0.21 & - & 0.21 \\
\hline
\end{tabular}

Based on Table 4, the effect of service quality on customer loyalty through customer satisfaction has a total effect of $0.29>$ direct effect 0.23 . This result shows that customer satisfaction mediates the influence of service quality on customer loyalty. The influence of corporate image on customer loyalty through customer satisfaction has total value effect $0.20>$ direct effect 0.16 . This result indicates that customer satisfaction mediates the influence of corporate image on customer loyalty. The influence of customer relationship marketing on customer loyalty through customer satisfaction has a total effect of $0.29>$ direct effect 0.22 . These results indicates that customer satisfaction mediates the influence of customer relationship marketing on customer loyalty tested.Thus, it is tested that customer satisfaction 
mediates the influence of service quality, corporate image, and customer relationship marketing on customer loyalty, and corporate image gives dominant influence to customer loyalty.

\section{Discussion and Conclusion}

\section{Quality of service, bank image, and customer relationship marketing affect customer} satisfaction

Customer satisfaction of bank customers is obtained from products that meet customer expectations. Products that meet customer expectations on bank services are determined by tangible service quality in the form of excellent bank staff performance. This means that customers demand bank officers to look attractive, because the appearance of bank staff will give the impression for the customer. In addition to service quality, corporate image in the form of availability of easy access services (ebanking) also makes customer satisfaction associated with the bank, without having to be tied to the day and working hours and bank location. Furthermore, banks build emotional closeness with customers by for example giving birthday congratulations. These findings support the result that service quality influences customer satisfaction conducted by Abdullah and Francine (2009), Kwortnik and Han (2013), Kim et al (2013), and Gunarathne (2014). Research on corporate image support affecting customer satisfaction performed by Herbig et al. (1994); Kuo and Tang (2013); Roche (2014); and Ghanian et al. (2014).

\section{Quality of service, bank image, and customer relationship marketing affect customer loyalty}

Loyal customers recommend to others, because they guarantee that only quality services will be accepted by other customers. Following this, in bank services just the quality of services do not make loyal customers; the positive image of the bank in the minds of customers is something of concern, because it relates to the credibility of the bank in guaranteeing customer funds. Thus, the ability of banks to build long-term relationships with customers also plays a role in retaining customers. The results of the present research creates significant influence between service quality and customer loyalty done by Al-Rousanand Mohamed (2010), Akbar et al. (2010), Malik et al. (2012), Bostanji (2013), and Poku et al. (2013), but the findings of this study do not support Cristobal et al. (2007). This research also supports the result that customer relationship marketing affects customer loyalty which is conducted by Jesri et al. (2013) and Wang and Yang (2010).

\section{Customer satisfaction affects customer loyalty}

Customer satisfaction affects customer loyalty. It can be explained that customers who feel satisfaction intend to repeat the transaction back at the bank and will recommend to others. The fulfillment of customer expectations such as making transactions with ease like knowing the balance information, transferring funds either with the same bank or with other banks, bill payment (PLN, Telkom, Credit Card, etc), purchasing other products, and knowing location information of the nearest ATM supported by GPS system are of great importance. The results of this study are in line with research conducted by Akbar et al. (2010), Mohajerani (2013), and Saleem and Raja (2014) indicating that customer satisfaction affects customer loyalty.

Customer satisfaction mediates the influence of service quality, bank image, and customer relationship marketing on customer loyalty

Customer satisfaction in the form of products that meet customer expectations encourages customers to save in the bank. Following this, access to services can be easy due to unlimited service and service time through the development of facilities. A comprehensive and 
integrated core banking system as well as customer relationship marketing, especially in building emotional closeness with customers will have an impact on the customer's attachment to the bank and will encourage customers to remain, not move to other banks, and recommend the bank to others.

Some limitations should be mentioned. Since the study was conducted only in bank, further research is needed in other organizations to compare the results. The research is also limited because the sample was comprised of bank customers; therefore, it may not be generalizable to other populations.

\section{References}

Abdullah, D. N. M. A., \& Francine, R. (2009). Influence of service and product quality towards customer satisfaction: A case study at the staff cafeteria in hotel industry (Working Paper No. 53). World Economy of Science, Engineering and Technology, Malaysia.

Akbar., S., Som, A. P. M.., Wadood, F., \& Alzaidiyeen, N. J. (2010). Revitalization of service quality to gain customer satisfaction and loyalty. International Journal of Business \& Management, 5(6), 113-123.

Al-Rousan, M. R., \& Mohamed, B. (2010). Customer loyalty and the impacts of service quality: The case of five star hotels in Jorand. International Journal of Human \& Social Sciences, 5(13), 886-892.

Assael, H. (1984). Consumer behavior and marketing action. Boston, MA: Kent.

Bloemer, J., Ruyter, K. D., \& Pascal, P. (1998). Investigating drivers of bank loyalty: The complex relationship between image, service quality and satisfaction. International Journal of Bank Marketing, 16(7), 276-286.

Bostanji, G. M. (2013). The impact of service quality on customers loyalty: A study on five stars hotel's customers in Riyadh, KSA. European Journal of Business \& Management, 5(31), 230-240.

Buttle, F. (2009). Customer relationship management: Concept and technologies. London, UK: Butterworth-Heinemann.

Cristobal, E., Flavian, C., \& Guinaliu, M. (2007). Perceived e-service quality (PeSQ) measurement validation and effects on consumer satisfaction and web site loyalty. Managing Service Quality, 17(3), 317-340.

Engle, J. F., Blackwell, R. D., \& Miniard, Paul, W. (1995). Consumer behavior.( $8^{\text {th }}$ ed.). Orlando: The Dryden Press.

Fornell, C. (1992). A national customer satisfaction barometer: The Swedish experience.Journal ofMarketing, 56(1),6-21.

Fornell, C., Johnson, M. D., Anderson, E. W., Cha, J., \& Bryant, B. E. (1996). The American customer satisfaction index: Nature, purpose, and findings. Journal of Marketing, 60(4), 7-18.

Foster, B. D., \& Cadogan, J. W. (2000). Relationship selling and customer loyalty: An empirical investigation. Marketing Intelligence \& Planning, 18(4), 185-199.

Ghanian, M., Ghoochani, O. M., \& Crotts, J. C. (2014). An application of European Performance Satisfaction Index towards rural tourism: The case of western Iran. Tourism Management Perspectives, 11, 77-82.

Griffin, J. (2002). Customer loyalty: How to earn it, how to keep it. USA: Jossey-Bass.

Gronroos, C. (1990). Service management and marketing: Managing the moment of truth in service competition. Massachusetts, USA: Lexington.

Gunarathne, U. (2014). Relationship between service quality and customer satisfaction in Sri Lankan Hotel Industry. International Journal of Scientific \& Research Publications, 4(11), 1-8.

Harrison, S. (2000). Public relation: An introduction. Cengage Learning EMEA.

Herbig, P., Milewicz, J., \& Golden, J. (1994). A model of reputation building and destruction. Journal of Business Research, 31(1), 23-31.

Jesri, P., Ahmadi, F., \& Fatehipoor, M. (2013). Effects of Relationship Marketing (RM) on customer loyalty (Case study: Mehr Bank, Kermanshah Province, Iran). Interdisciplinary Journal of Contemporary Research in Business, 4(11), 304312.

Kim, S. H., Cha, J., Singh, A. J., \& Knutson, B. J. (2013). A longitudinal investigation to test the validity of the American customer satisfaction model in the U. S. hotel industry. International Journal of Hospitality Management, 35, $193-202$.

Kotler, P., \& Keller, K. L. (2006). Marketing Management (12 ${ }^{\text {th }}$ ed.). Upper Saddle River: Pearson Prentice Hall.

Kotler, P., \& Armstrong, G. (2008). Principles of marketing. London: Prentice Hall. 
Kuo, C. W., \& Tang, M. L. (2013). Relationships among service quality, corporate image, customer satisfaction, and behavioral intention for the elderly in high-speed rail services. Journal of Advanced Transportation, 47(5), 512-525.

Kwortnik, R. J. Jr., \& Han, X. (2011). The influence of guest perceptions of service fairness on lodging loyalty in China. Cornell Hospitality Quarterly, 52(3), 321-332.

Lu, Y., \& Liping, A. C. (2009). Analysis of image and loyalty forexhibitions and host destinations. Hospitality and Tourism Management, International CHRIE Conference-Refereed Track.

Malik, F., Yaqoob, S., \& Aslam, A. S. (2012). The impact of price perception, service quality, and brand image on customer loyalty (study of hospitality industry in Pakistan). Interdisciplinary Journal of Contemporary Research in Business, 4(5), 487-505.

Milfelner, B., Snoj, B., \& Korda, A. P. (2011). Measurement of perceived quality, perceived value, image and satisfaction interrelations of hotel services: Comparison of tourists from Slovenia and Italy. Drustvena Istrazivanja, 20(3), 605-624.

Mohajerani, P. (2013). Customer satisfaction: A structural equation modeling analysis. Australian Journal of Business \& Management Research, 3, 1-10.

Ndubisi, N. O. (2007). Relationship marketing and customer loyalty. Marketing Intelligence \& Planning, 25(1), 98-106.

Ndubisi, N. O., \& Wah, C. K. (2005). Factorial and discriminant analyses of the underpinning of relationship marketing and customer satisfaction. International Journal of Bank Marketing, 23(7), 542-557.

Nguyen, T. H., Sherif, J. S., \&Newby, M. (2007). Strategies for successful CRM implementation. Information Management \& Computer Security,15(2), 102-115.

Oliver, R. L. (1997).Satisfaction: A behavioral perspective on the consumer. New York, NY: McGraw-Hill.

Parasuraman, A., Zeithaml, V. A., \& Berry, L., L. (1988). A multiple-item scale for measuring customer perception of service quality. Journal of Retailing, 64(1), 12-40.

Peter, J. P., \& Olson, J. C. (200599). Consumer behavior and marketing strategy ( $7^{\text {th }}$ ed.). Boston, MA: Mc GrawHill.

Poku, K., Zakari, M., \& Soali. A. (2013). Impact of service quality on customer loyalty in the hotel industry: An empirical study from Ghana. International Review of Management \&Business Research, 2(2), 600-609.

Robinson, S. (1999). Measuring service quality: Current thinking and future requirements. Marketing Intelligence Planning, 17(1), 21-32.

Roche, I. Dharmaratne. (2014). An empirical investigation of internet banking service quality, corporate image and the impact on customer satisfaction: With special reference to Sri Lankan Banking sector. Journal of Internet Banking \& Commerce, 19(2), 1-18.

Saleem, H., \& Raja, N. S. (2014). The impact of service quality on customer satisfaction, customer loyalty and brand image: Evidence from hotel industry of Pakistan. Middle-East Journal of Scientific Research, 19(5), 706-711.

Sung, J. Y., \& Young, J. C. (2005). An exploratory research on the store image attributes affecting its store loyalty. Seoul Journal of Business, 11(1), 19-41.

Tse, D. K., \& Wilton, P. C. (1988). Models of consumer satisfaction formation: An extension. Journal of Marketing Research, 25, 204-212.

Wang, M. L., \& Yang, F. F. (2010). How does CRM create better customer outcomes for small educational institutions? African Journal of Business Management, 4(16), 3541-3549.

Zeithaml, V. A., \& Bitner, M. J. (2003). Services marketing. integrating customer focus across the firm. New York: Irwin McGraw-Hill. 